\title{
PENDIDIKAN ISLAM DALAM PERSPEKTIF NEO-MODERNISME (Studi Analisis Pemikiran Fazlur Rahman)
}

\section{Muhammad Hamsah}

Institut Agama Islam Negeri Salatiga

E-Mail:muhammadhamsah27@yahoo.com

\section{Nurchamidah}

Institut Agama Islam Negeri Salatiga

E-Mail: idamida676@gmail.com

\begin{tabular}{|c|c|c|}
\hline Received & Revised & Accepted \\
\hline 4 July 2019 & 2 Agustus 2019 & 20 Agustus 2019 \\
\hline
\end{tabular}

\section{ISLAMIC EDUCATION IN NEO-MODERNISME PERSPECTIVE (An Analysis Study of Fazlur Rahman Thinking)}

\begin{abstract}
Fazlur Rahman offers an Islamic Neo-Modernism as a new approach especially in the Islamic education. Neo-Modernism is a description system about Muslims conditions that is different from modernism, traditionalism, salafi, fundamentalism, and others. For Rahman, a new description system is necessary, remembering the modernism era, the connection between modernity with Islam and traditionalism with fundamentalism, there is a crisis. Fazlur Rahman has the view that Islamic higher education is called Islamic intellectualism. This Islamic intellectualism, is the use of q aql (intellectual, ratio), in order to gain knowledge and learning from natural phenomena found in life. Islamic intellectualism can also be understood that someone who can interpret Islam in rational and scientific themes to meet the needs of a progressive modern society. The virtue of Islamic education should be visible and color the fresh and advanced human life. This can occur when responding to various findings and developments today.
\end{abstract}

Keywords: Islamic education, Islamic intelectualism, and neomodernism. 


\begin{abstract}
Abstrak
Fazlur Rahman menawarkan Neo-Modernisme Islam sebagai pendekatan baru terutama pada ranah pendidikan Islam. Neo-Modernisme merupakan suatu sistem penjelasan tentang kondisi umat Islam yang berbeda dengan modernisme, tradisionalisme, salafi, fundamentalisme, dan lain-lain. Bagi Rahman, sistem penjelasan baru sangat diperlukan, mengingat era modernisme, hubungan modernitas dengan Islam serta tradisionalisme dengan fundamentalisme, terdapat krisis. Fazlur Rahman memiliki pandangan bahwa pendidikan tinggi Islam yang disebut dengan intelektualisme Islam. Intelektualisme Islam ini, merupakan penggunaan 'aql (intelektual, rasio), supaya memperoleh pengetahaun dan pembelajaran dari fenomena alam yang ditemukan dalam kehidupan. Intelektualisme Islam ini juga bisa dipahami bahwa seseorang yang bisa menafsirkan Islam dalam tema-tema rasional dan ilmiah untuk memenuhi kebutuhan suatu masyarakat modern yang progresif. Keutamaan pendidikan Islam mestinya nampak dan mewarnai kehidupan manusia yang segar dan maju. Hal ini bisa terjadi ketika merespon berbagai penemuan dan perkembangan masa kini.
\end{abstract}

Kata Kunci: Pendidikan Islam, Intelektualisme Islam, dan Neomodernisme

\title{
Pendahuluan
}

Pemikiran Pendidikan Islam dipahami sebagai suatu usaha sungguh-sungguh disertai sikap merdeka dan berani menggali serta merumuskan konsep pendidikan Islam untuk mentransformasikan ajaran Islam sebagai sumber nilai. Dengan demikian, diharap Islam akan mewarnai segala aspek kehidupan yang berperadaban. Sumber Daya Manusia (SDM) dapat dikembangkan melalui pendidikan dengan memerlukan wawasan yang luas, terbuka, inovatif, dan selalu selaras dengan kondisi zaman. Mengingat pendidikan meliputi aspek kehidupan manusia, baik menyangkut pemikiran, pengalaman dan pengamalannya.

Kondisi pendidikan di sekolah dan perguruan tinggi formal pada saat modernisme berkembang dan berkuasa dalam bentang sejarah utamanya abad 18 , ke-19 apalagi abad ke-20 melahirkan pandangan yang dikotomis antara Islam tradisional dan modernis. Diantaranya di anak benua India, Turki, Mesir, serta beberapa negara Muslim lainnya di kawasan Asia, termasuk Indonesia. Dalam pandangan pemikir Islam di era awal abad ke 20, memandang cara ini ibarat seperti dua rel kereta api yang berdampingan dan tidak akan pernah bertemu. Demikian itu berpengaruh besar terhadap krisis moralitas dan keimanan. Di mana ketika ini dibiarkan berlarut, maka garis Islam tradisional semakin ketinggalan dan terkalahkan, karena lebih banyak memilih mempertahankan diri dan bernostalgia dengan kejayaan masa lalu. Sebaliknya garis modernis akan semakin mensekulerkan ilmu dan pengetahuan yang akan mengikis keimanan dan moralitas manusia karena pandangannya yang terlalu saintifik, positivistic logic.

Sayyid Ahmad Khan dengan mudah bisa dikatakan sebagai yang paling radikal menerima modernis. Baginya optimis bahwa semangat ilmiah modern atau hukum-hukum alam harus menjadi kriteria untuk menilai bisa diterima atau 
tidaknya suatu agama. Kaum Muslimin terdahulu telah salah paham besar dan mensalah-tafsirkan pandangan dunia al-Qur'an di masa lampau, dan karena theologi Muslim ortodoks tidak lagi absah, maka suatu teologi yang baru mesti disusun dari al-Qur'an dalam sinaran pengalaman modern. Ahmad Khan berupaya mempergunakan argumen-argumen Mu'tazilah dan filsuf Muslim.

Pandangan-pandangannya yang radikal, maka ia tidak mampu mengaplikasikannya di akademi Muslim Aligarh yang didirikannya sendiri dengan tujuan melakukan perjumpaan keyakinan agama dengan pandangan ilmiah modern. Pada akhirnya pendidikan agama di Aligarh terpaksa diserahkan kepada guru-guru tradisionalis yang tidak memiliki pendidikan modern apapun ${ }^{1}$. Sikap modernis (sekuler), tidak menjadikan ayat-ayat al-Qur'an sebagai sistem makna. Misal, berbicara tentang kemiskinan, mereka tidak memerlukan ayat, mereka tinggal menghitung dan menentukan teknisnya ${ }^{2}$.

Inilah yang menyebabkan banyak reaksi dan kekhawatiran dari intelektual dan sarjana-sarjana Muslim, akan hilangnya nilai-nilai Qur'an sebagai pijakan. Diantaranya Muhammad Iqbal mengecam keras pengetahuan modern, yang baginya nampak hampir seluruh condong kepada teknologi dan materialisme dan bersifat merusak nilai-nilai manusia yang lebih tinggi. Bagi Iqbal, bahwa pendidikan tradisional juga gagal mencapai tujuan, kesulitan terbesarnya karena telah menciptakan dualisme antara agama dengan sekuler, antara dunia dan akhirat.

Sarjana "agama” (ulama) telah menjadi ahli yang "profesional" dibidangnya, namun ia tidak bisa menyelesaikan permasalahan di tempat mereka hidup. Bagi Iqbal, pembuktian kehidupan religius dan spiritual adalah bahwa permasalahan bisa diselesaikan secara kreatif. Iqbal sepakat bahwa, sistem pendidikan tradisional memenjarakan otak dan jiwa dalam kurungannya. Sedangkan pendidikan modern memberikan pendidikan materialistis yang kurang sesuai dengan nilai-nilai kemanusiaan terpuncak dalam budaya spiritual Islam. Juga mengindoktrinasi generasi muda Islam dengan superioritas kebudayaan Barat ${ }^{3}$.

Respon intelektual Muslim sebagai solusi terhadap dominasi modernis memunculkan berbagai khazanah pemikiran Islam, baik secara "text to text", "text to context", atau "in their meaning of the text". Model perubahan dan dinamika pengembangan pemikiran terhadap pendidikan Islam selalu berganti seiring perkembangan pemikiran Islam ke setiap masa ${ }^{4}$. Jadi ternyata paradigma tentang pendidikan Islam, sangat banyak dipengaruhi oleh paradigma tentang Islam itu sendiri. Bukti bahwa pemikiran pendidikan Islam selalu berganti seiring siklus pemikiran keislaman. Setidaknya ada empat model pemikiran yang telah ada dan

\footnotetext{
${ }^{1}$ Fazlur Rahman, “Islam Dan Modernitas: Tentang Transformasi Intelektual, Terj,” Ahsin Muhammad, Bandung: Pustaka 1 (1985).

${ }^{2}$ Syarif Hidayatullah, Intelektualisme Dalam Perspektif Neo-Modernisme (Tiara Wacana Yogya, 2000).

${ }^{3}$ Rahman, "Islam Dan Modernitas: Tentang Transformasi Intelektual, Terj."

${ }^{4}$ IBNUDIN FAUZAN, "THE THINKING OF CONTEMPORARY ISSUES IN ISLAMIC WORLD (PEMIKIRAN ISU-ISU KONTEMPORER DALAM DUNIA KEISLAMAN)," Al-Afkar, Journal For Islamic Studies 3, no. 1 (2019): 35-47.
} 
masing-masing tetap banyak yang memilih sebagai pandangan hidup. ${ }^{5}$ Keempat model ini dapat membantu menelusuri jejak dan ruang-ruang interpretasi Islam:

Model pertama (Tekstualis Salafi) berupaya memahami Qur'an dan Sunnah yang shahih dalam hal nilai dan ajaran yang dikandungnya. Melepaskan diri dari atau sedikit pertimbangan dari keadaan konteks pergumulan masyarakat Muslim (era klasik maupun kontemporer) yang mengintarinya. Model masyarakat yang didambakan yaitu model salaf, di mana sistem komunitas atau masyarakat yang sama dengan pola di masa Rasulullah bersama para sahabat di sekelilingnya. Cara berpikir dan bertindak berdasarkan Qur'an dan hadis dengan berdiri sendiri dalam artian tidak bisa di integrasikan dengan ilmu yang lain. Mereka beranggapan bahwa melestarikan budaya salaf merupakan hal yang paling mendasar dijaga keberadaanya sampai sekarang, karena diyakini seabgai model yang paling tepat. Model ini bersifat konservatif, karena berupaya mempertahankan nilai, kebiasaan dan tradisi masyarakat terdahulu ${ }^{6}$.

Model kedua (Tradisionalis Mazhabi) berusaha memahami nilai dan ajaran mendasar di dalam Qur'an dan Sunnah al-Sahih, dengan kehadiran warisan pemikiran Islam masa dulu, namun seringkali kurang mempertimbangkan situasi sosio-historis masyarakat setempat. Dalam ranah pendidikan dan pengaplikasiannya selalu merujuk pada hasil pemikiran ulama terdahulu yang dianggap sudah pasti atau absolut tanpa mempertimbangkan dimensi historisnya. Masyarak Muslim yang di cita-citakan adalah masyarakat Muslim klasik, dengan anggapan bahwa hal-hal mengenai agama sudah dikupas tuntas para pendahulu dari kalangan intelektual, ulama, cendekiawan Islam. Cara berpikirnya selalu merujuk pada hasil ijtihad ulama, intelektul dan cendekiawan terdahulu mengenai menyelesaikan persoalan ketuhanan, manusia dan kemasyarakatan ${ }^{7}$.

Model ketiga (modernis), berusaha memahami ajaran dan nilai mendasar yang terkandung dalam Qur'an dan Sunnah dengan hanya fokus dalam mempertimbangkan kondisi, tantangan sosio-historis dan kultural yang dihadapi oleh masyarakat Muslim kontemporer yang ditandai perkembangan iptek, sains dan perkembangan ilmu lainnya yang kekinian tanpa mempertimbangkan hasil kreativitas dan pemikiran intelektual Muslim salaf, klasik mengenai persoalan keagamaan dan kemasyarakatan. Model demikian terburu-buru terhadap penggalian dan penelusuran khazanah pemikiran Islam klasik atau terdahulu, dan cenderung menempuh jalan pintas, yaitu berkeinginan secara langsung masuk dalam arena tekhnologi modern dengan mengabaikan warisan intelektual Islam terdahulu. Metode yang ditempuhnya yaitu berusaha memahami nash Al-Qur'an secara langsung kemudian meloncat ke peradaban era modern. Dalam pendidikan, hal ini biasa disebut Progressivism. Progressivism menghendaki sikap bebas dan modifikatif, tujuan pendidikan dimaknai suatu rekonstruksi pengalaman yang

\footnotetext{
${ }^{5}$ Muhammad Hamsah, Liberalisme Mendobrak Pemikiran Ortodoks (Kritik Islam Liberal Terhadap Pemikiran Pendidikan Islam Ortodoks Di Indonesia, (Makassar: Skripsi UIN Alauddin, 2015), h. 132.

${ }^{6}$ Muhaimin, Pemikiran Dan Aktualisasi Pengembangan Pendidikan Islam (Rajawali Pers, 2011).

${ }^{7}$ Muhaimin.
} 
berkepanjangan, supaya peserta didik mampu berbuat sesuatu yang intelegen serta bisa mengadakan penyesuaian sesuai tuntutan dari lingkungan ${ }^{8}$.

Model keempat (Neo Modernis) berusaha memahami ajaran dan nilai mendasar yang terkandung dalam Qur'an dan Sunnah al sahihah dengan mengikutsertakan dan mempertimbangkan warisan intelektual Islam klasik serta mencermati kesulitan maupun kemudahan yang ditawarkan oleh peradaban teknologi modern. Jadi pola ini selalu mempertimbangkan Qur'an dan Sunnah, khazanah pemikiran Muslim klasik, serta pendekatan keilmuan yang lahir pada abad 19 dan 20 M. Slogan yang sering didengunkan yaitu "al-Muhafazah 'ala al-Qadim alSalih wa al-Akhzu bi-al jadid al-Aslah", yaitu memelihara hal yang baik yang sudah ada di samping itu juga mengembangkan nilai dan hal baru yang lebih baik.

Kata “al-Muhafazah 'ala al-Qadim al-salih", menggarisbawahi adanya unsur parennialism dan essensialism, yakni sikap regresif dan konservatif terhadap nilainilai Ilahi dan nilai-nilai insani (budaya manusia) yang telah ada, yang telah dibangun serta dikembangkan oleh para pemikir dan masyarakat terdahulu. Namun sikap demikian lahir setelah dilakukan kontekstualisasi, dengan kata lain, meletakkan khazanah intelektual Islam klasik dalam konteksnya. Pemikiranpemikiran demikian terus menuai badai kritik, diperdebatkan atau dikecam, terutama dalam konteks berlakunya pada masa sekarang. Hal yang dianggap relevan akan dilestarikan, sebaliknya yang dianggap kurang relevan akan disikapi dengan cara mencari alternatif lain yang terbaik atau "al-Akhzu bi al-jadid al-Aslah", dalam hal pendidikan masyarakat Muslim kontemporer. Istilah lainnya adalah menunjukkan adanya sikap dinamis dan progresif serta sikap rekonstruktif 9 .

Dari sekelumit dinamika modernis sampai babak penghujung, muncullah berbagai intelektual Islam yang berupaya mengadakan pembaruan pemikiran dan merumuskan konsep ideal yang bisa jadi alternatif, di antaranya adalah Fazlur Rahman. Tokoh ini jika dicermati secara mendalam pemikiran dan tulisantulisannya, maka bisa dikatakan adalah juru bicara dalam tradisi kritik modern. Namun tampaknya tokoh ini banyak perbedaan dibanding berbagai pemikir pasca modernism lainnya, baik dari segi pemikiran dan konsep, maupun dari segi metodologi, semua itu ditawarkan sebagai jalan alternatif mengatasi gerakan modernis.

Fazlur Rahman menawarkan Neo-Modernisme Islam. Ini merupakan pendekatan baru, baik dalam pengkajian ajaran-ajaran Islam, maupun pengkajian Barat. Neo-Modernisme merupakan suatu sistem penjelasan tentang kondisi umat Islam yang berbeda dengan modernisme, tradisionalisme, fundamentalisme, dan lain-lain. Bagi Rahman, sistem penjelasan baru sangat diperlukan, mengingat era modernisme, hubungan modernitas dengan Islam serta tradisionalisme dengan fundamentalisme, terdapat krisis ${ }^{10}$.

\footnotetext{
${ }^{8}$ Muhaimin.

${ }^{9}$ Muhaimin.

${ }^{10}$ Hidayatullah, Intelektualisme Dalam Perspektif Neo-Modernisme.
} 


\section{Metode Penelitian}

\section{Jenis Penelitian}

Dalam penelitian ini, peneliti menggunakan pendekatan kualitatif. Pendekatan kualitatif, dikaitkan dengan epistemologi interpretatif, yang biasanya digunakan untuk pengumpulan dan analisis data yang menyandarkan pada pemahaman, dengan penekanan pada makna-makna yang terkandung di dalamnya atau yang ada di balik kenyataan-kenyataan yang teramati ${ }^{11}$. Jenis penelitian kepustakaan (Library Research), selanjutnya peneliti menganalis data yang dilakukan secara terus menerus, dilakukan sejak pertama data dikumpulkan, sehingga diperoleh kesimpulan awal yang masih belum pasti. Untuk memantapkan kesimpulan tersebut agar berdasar pada data dasar (grounded) maka verifikasi dilakukan sepanjang proses penelitian, dengan maksud menjamin kerandalan (reliabilitas) hasil penelitian ${ }^{12}$.

Dengan demikian penulis dapat mendeskripsikan suatu narasi berdasarkan acuan. Penulis menggunakan penelitian kualitatif deskriptif bersifat kepustakaan mengenai konsep pendidikan Islam neo-modernisme perspektif Fazlur Rahman.

\section{Teknik pengumpulan data}

a. Observasi deskriptif

Observasi deskriptif dilakukan peniliti ketika memasuki situasi sosial tertentu sebagai objek penelitian. Tahap ini peneliti belum membawa masalah yang akan diteliti, dilakukanlah penjelajahan umum dan menyeluruh, memberi interpretasi pada semua yang dilihat, dirasakan, di dengar. Peneliti melakukan analisis domain, sehingga deskripsi mampu dilakukan pada semua hal yang ditemui ${ }^{13}$.

\section{b. Teknik Dokumen}

Dokumentasi adalah catatan peristiwa yang telah lewat. Dokumen bisa berupa peninggalan tertulis seperti tulisan, sejarah kehidupan, gambar atau karyakarya monumental yang dibuat seseorang. Studi dokumen merupakan pelengkap dari penggunaan metode observasi dan wawancara dalam penelitian kualitatif. ${ }^{14}$

\section{Teknik Analisis Data}

Analisis data pada penelitian kualitatif dilakukan sejak sebelum memasuki lapangan, selama dilapangan, dan setelah selesai di lapangan. Penelitian menggunakan analisis data kualitatif yang bersifat deduktif, yaitu suatu analisis berdasarkan data yang telah diperoleh, kemudian dikhususkan dengan pola

\footnotetext{
${ }^{11}$ Hamid Patilima, “Metode Penelitian Kualitatif (Edisi Revisi)," Bandung: Penerbit Alfabeta, 2011.

${ }^{12}$ Lexy J Moleong and Tjun Surjaman, Metodologi Penelitian Kualitatif (Penerbit PT Remaja Rosdakarya, 1991).

${ }^{13}$ Sugiyono, Metode Penelitian Pendidikan:(Pendekatan Kuantitatif, Kualitatif Dan R \& D) (Alfabeta, 2008).

${ }^{14}$ Sugiyono, Metode Penelitian Kuantitatif, Kualitatif dan R\&D, h. 240.
} 
hubungan tertentu. Penelitian ini dapat diperoleh dari berbagai sumber kemudian dikumpulkan yang akan dijadikan sumber dalam penelitian. Dari data yang telah didapat, peneliti menganalisis sebagai berikut:

a. Biografi Singkat Fazlur Rahman

b. Konsep Pemikiran Pendidikan Islam menurut Fazlur Rahman

c. Metodologi Neo-Modernisme dalam pembaruan Islam dan pendidikan Islam.

d. Relevansi Pemikiran Pendidikan Islam Fazlur Rahman dalam Konteks Pendidikan Islam di Indonesia.

\section{Hasil dan Pembahasan}

\section{Biografi Singkat Fazlur Rahman}

Fazlur Rahman lahir pada tanggal 21 September 1919 di Hazara, suatu daerah di Anak Benua Indo-Pakistan yang sekarang terletak di barat laut Pakistan. Wilayah Anak Benua Indo-Pakistan telah melahirkan banyak pemikir Islam yang cukup berpengaruh dalam perkembangan pemikiran Islam, seperti Syah Wali Allah, Sir Sayyid Ahmad Khan, hingga Sir Muhammad Iqbal. Nama keluarga Fazlur Rahman adalah Malak, namun nama keluarga Malak ini tidak pernah digunakan dalam daftar referensi baik di Barat ataupun di Timur. Fazlur Rahman dilahirkan dalam suatu keluarga Muslim yang sangat religius. Kerelegiusan ini dinyatakan oleh Fazlur Rahman sendiri yang bahwa ia mempraktekan ibadah-ibadah keisalaman seperti shalat, puasa, dan lainnya, tanpa meninggalkannya sekalipun. Dengan latar belakang kehidupan keagamaan yang demikian, maka menjadi wajar ketika berumur sepuluh tahun ia sudah dapat menghafal Alquran.

Adapun mazhab yang dianut oleh keluarganya ialah mazhab Hanafi. Walaupun hidup ditengah-tengah keluarga mazhab Sunni, Fazlur Rahman mampu melepaskan diri dari sekat-sekat yang membatasi perkembangan intelektualitasnya dan keyakinan-keyakinannya ${ }^{15}$. Dengan demikian, Fazlur Rahman dapat mengekspresikan gagasan-gagasannya secara terbuka dan bebas. Seperti pendapat mengenai wajibnya shalat tiga waktu yang dijalani oleh penganut mazhab Syi'ah, Fazlur Rahman beranggapan bahwa praktek tersebut dibenarkan secara historis karena Muhammad saw. pernah melakukannya tanpa sesuatu alasan.

Orang tua Fazlur Rahman sangat mempengaruhi pembentukan watak dan keyakinan awal keagamaannya. Melalui ibunya, Rahman memperoleh pelajaran berupa nilai-nilai kebenaran, kasih sayang, kesetiaan, dan cinta. Ayah Fazlur Rahman merupakan penganut mazhab Hanafi yang sangat kuat, namun beliau membu diri dari pendidikan modern. Tidak seperti penganut mazhab Hanafi fanatik lainnya ketika itu, Ayahnya berkeyakinan bahwa Islam harus memandang modernitas sebagai tantangan-tantangan dan kesempatan-kesempatan. Pandangan

\footnotetext{
${ }^{15}$ Asep Arsyul Munir, "AGAMA, POLITIK DAN FUNDAMENTALISME," Al-Afkar, Journal For Islamic Studies 1, no. 1 (2018): 149-69.
} 
ayahnya inilah yang kemudian mempengaruhi pemikiran dan keyakinan Fazlur Rahman. Selain itu, melalui tempaan ayahnya, Fazlur Rahman pada kemudian hari menjadi seorang yang bersosok cukup tekun dalam mendapatkan pengetahuan dari pelbagai sumber, dan melalui ibunyalah kemudian ia sangat tegar dan tabah dalam mengembangkan keyakinan dan pembaruan Islam.

Pada tahun 1933, Fazlur Rahman melanjutkan pendidikannya di sebuah sekolah modern di Lahore. Selain mengenyam pendidikan formal, Fazlur Rahman pun mendapatkan pendidikan atau pengajaran tradisinonal dalam kajian-kajian keislaman dari ayahnya, Maulana Syahab al Din. Materi pengajaran yang diberikan ayahnya ini merupakan materi yang ia dapat ketika menempuh pendidikan di Darul Ulum Deoband, di wilayah utara India. Ketika berumur empat belas tahun, Fazlur Rahman sudah mulai mempelajari filsafat, bahasa Arab, teologi atau kalam, hadis dan tafsir.

Setelah menyelesaikan pendidikan menengahnya, Rahman kemudian melanjutkan pendidikan dengan mengambil bahasa Arab sebagai kosentrasi studinya dan pada tahun 1940 ia berhasil mendapatkan gelar Bachelor of Art. Dua tahun kemudian, tokoh utama gerakan neomodernis Islam ini berhasil menyelesaikan studinya di universitas yang sama dan mendapatkan gelar Master dalam bahasa Arab. Ketika telah menyelesaikan studi Masternya dan tengah belajar untuk menempuh program Doktoral di Lahore, Fazlur Rahman pernah diajak oleh Abul A'la Mauwdudi, yang kelak menjadi "musuh" intelektualitasnya, untuk bergabung di Jama’at al Islami dengan syarat meninggalkan pendidikannya.

Pada tahun 1946, Fazlur Rahman berangkat ke Inggris untuk melanjutkan studinya di Oxford University. Keputusannya untuk melanjutkan studinya di Inggris dikarenakan oleh mutu pendidikan di India ketika itu sangat rendah. Dibawah bimbingan Profesor S. Van den Berg dan H A R Gibb, Fazlur Rahman berhasil menyelesaikan studinya tersebut dan memperoleh gelar $\mathrm{Ph}$. D pada tahun 1949 dengan disertasi tentang Ibnu Sina. Disertasi Fazlur Rahman ini kemudian diterbitkan oleh Oxford University Press dengan judul Avicenna's Psychology. Selama menempuh pendidikan di Barat, Fazlur Rahman menyempatkan diri untuk belajar pelbagai bahasa asing. Bahasa-bahasa yang berhasil dikuasai olehnya diantaranya ialah Latin, Yunani, Inggris, Jerman, Turki, Arab dan Urdu. Penguasaan pelbagai bahasa ini membantu Fazlur Rahman dalam memperdalam dan memperluas cakrawala keilmuannya (khususnya studi keislaman) melalui penelusuran pelbagai literatur.

Setelah menyelesaikan studinya di Oxford University, Fazlur Rahman tidak langsung ke negeri asalnya Pakistan (ketika itu sudah melepaskan diri dari India), ia memutuskan untuk tinggal beberapa saat disana. Ketika tinggal di tinggal di Inggris, Fazlur Rahman sempat mengajar di Durham University. Kemudian pindah mengajar ke Institute of Islamic Studies, McGill University, Kanada, dan menjabat sebagai Associate Professor of Philosophy sampai awal tahun 1960. Menurut pengakuan Fazlur Rahman, ketika menempuh studi pascasarjana di Oxford University dan mengajar di Durham University, konflik antara pendidikan modern yang diperolehnya di Barat dengan pendidikan Islam tradisional yang didapatkan ketika 
di negeri asalnya mulai menyeruak. Konflik ini kemudian membawanya pada skeptisisme yang cukup dalam, yang diakibatkan studinya dalam bidang filsafat.

Setelah tiga tahun mengajar di McGill University, akhirnya pada awal tahun 1960 Fazlur Rahman kembali ke Pakistan setelah sebelumnya diminta bantunnya oleh Ayyub Khan untuk membangun negeri asalnya, Pakistan. Menurut, permintaan Ayyub Khan kepada Fazlur Rahman ialah bertujuan untuk membawa Pakistan pada khittah berupa negara yang bervisi Islam Selanjutnya pada tahun 1962, Fazlur Rahman diminta oleh Ayyub Khan untuk memimpin Lembaga Riset Islam (Islamic Research Institute) dan menjadi anggota Dewan Penasihat Ideologi Islam (The Advisory Council of Islamic Ideology). Motivasi Fazlur Rahman untuk menerima tawaran dari Ayyub Khan dapat dilacak pada keinginannya untuk membangkitkan kembali visi Alquran yang dinilainya telah terkubur dalam puing-puing sejarah.

Kursi panas yang diduduki oleh Fazlur Rahman akhirnya menuai berbagai reaksi. Para ulama tradisional menolak jika Fazlur Rahman mendudukinya, ini disebabkan oleh latar belakang pendidikannya yang ditempuh di Barat. Penentangan atas Fazlur Rahman akhirnya mencapai klimaksnya ketika jurnal Fikr-o-Nazar menerbitkan tulisannya yang kemudian menjadi dua bab pertama bukunya yang berjudul Islam. Pada tulisan tersebut, Fazlur Rahman mengemukakan pikiran kontroversialnya mengenai hakikat wahyu dan hubungannya dengan Muhammad saw. Menurut Fazlur Rahman, Alquran sepenuhnya adalah kalam atau perkataan Allah swt, namun dalam arti biasa, Alquran juga merupakan perkataan Muhammad saw.

Akibat pernyataan-pernyataannya tersebut, Fazlur Rahman dinyatakan sebagai munkir-i-Quran (orang yang tidak percaya Alquran). Kontroversi dalam media masa Pakistan mengenai pemikiran Fazlur Rahman tersebut berlalu hingga kurang lebih satu tahun, yang pada akhirnya kontroversi ini membawa pada gelombang demonstrasi massa dan mogok total di beberapa daerah Pakistan pada September 1968. Menurut hampir seluruh pengkaji pemikiran Fazlur Rahman berpendapat bahwa penolakan atasnya bukanlah ditujukan kepada Fazlur Rahman tetapi untuk menentang Ayyub Khan. Hingga akhirya pada 5 September 1968 permintaan Fazlur Rahman untuk mengundurkan diri dari pimpinan Lembaga Riset Islam dikabulkan oleh Ayyub Khan.

Pada akhir tahun 1969 Fazlur Rahaman meninggalkan Pakistan untuk memenuhi tawaran Universitas California, Los Angeles, dan langsung diangkat menjadi Guru Besar Pemikiran Islam di universitas yang sama. Mata kuliah yang ia ajarkan meliputi pemahaman Alquran, filsafat Islam, tasawuf, hukum Islam, pemikiran politik Islam, modernism Islam, kajian tentang al Ghazali, Shah Wali Allah, Muhammad Iqbal, dan lain-lain. Salah satu alasan yang menjadikan Rahman memutuskan untuk mengajar di Barat disebabkan oleh keyakinan bahwa gagasangagasan yang ditawarkannya tidak akan menemukan lahan subur di Pakistan. Selain 
itu, Rahman menginginkan adanya keterbukaan atas pelbagai gagasan dan suasana perdebatan yang sehat, yang tidak ia temukan di Pakistan. ${ }^{16}$

Selama di Chicago, Rahman mencurahkan seluruh kehidupannya pada dunia keilmuan dan Islam. Kehidupannya banyak dihabiskan di perpustakaan pribadinya di basement rumahnya, yang terletak di Naperville, kurang lebih 70 kilometer dari Universitas Chicago. Rahman menggambarkan aktitivitas dirinya tersebut laiknya ikan yang naik ke atas hanya untuk mendapatkan udara. Dari konsistensinya dan kesungguhannya terhadap dunia keilmuan akhirnya Rahman mendapatkan pengakuan lembaga keilmuan berskala internasional. Pengakuan tersebut salah satunya ialah pada tahun 1983 ia menerima Giorgio Levi Della Vida dari Gustave E von Grunebaum Center for Near Eastern Studies, Universitas California, Los Angeles.

Pada pertengahan dekade 8o-an, kesehatan tokoh utama neomodernisme Islam tersebut mulai terganggu, dintaranya ia mengidap penyakit kencing manis dan jantung. Konsistensi Rahman untuk terus berkarya pun ditandai oleh lahirnya karya yang berjudul Revival and Reform in Islam: A Study of Islamic Fundamentalism. Walaupun baru diterbitkan setelah beliau wafat, namun pengerjaannya dilakukan ketika sakit beliau makin parah dengan dibantu oleh puteranya. Akhirnya, pada 26 Juli 1988 profesor pemikiran Islam di Univesitas Chicago itu pun tutup usia pada usia 69 tahun setelah beberapa lama sebelumnya dirawat di rumah sakit Chicago ${ }^{17}$.

\section{Konsep Pemikiran Pendidikan Islam Fazlur Rahman}

Fazlur Rahman nampaknya mengkritik pendidikan Islam yang ditawarkan dan dipraktekkan kelompok tradisional dan modernis, sebagaimana penuturannya bahwa, dalam karya-karya istimewa filosof individual yang pemikiran mereka, pada gilirannya bereaksi terhadap tradisi ortodoks. Dalam dampak yang baru ini, kaum ortodoks menciptakan sejumlah ruang tertentu bagi intelektualisme dalam disiplindisiplin pendidikan mereka, tetapi dengan itu juga secara efektif membatasi perkembangan baik filsafat maupun sains-sains rasional yang sistematis. Kesempitan dan kekakuan relatif dari pendidikan dalam madrasah-madrasah (sekolah-sekolah theologi) waktu itu, sungguh terutama bertanggungjawab atas kemacetan intelektual Islam selanjutnya. Khususnya yang sangat disayangkan sekali adalah sikap kaum ulama terhadap "sains-sains sekular", yang tampaknya mencekik semangat utama penyelidikan dan bersama dengan itu seluruh pertumbuhan ilmu pengetahuan positif ${ }^{8}$.

Zaman modern merupakan zaman kebangkitan umat Islam. Jatuhnya Mesir ke tangan Barat menginsyafkan dunia Islam akan kelemahannya dan menyadarkan umat Islam bahwa Barat telah timbul peradaban baru yang lebih tinggi dan merupakan ancaman bagi Islam. Raja-raja dan pemuka-pemuka Islam mulai

\footnotetext{
${ }^{16}$ Fazlur Rahman Kajian Terhadap Metode Sutrisno and Fazlur Rahman Kajian terhadap Metode,

"Epistemologi Dan Sistem Pendidikan," Yogyakarta: Pustaka Pelajar, 2006.

${ }^{17}$ Abuddin Nata, Pemikiran Pendidikan Islam \& Barat (PT RajaGrafindo Persada, 2012).

${ }^{18}$ Rahman, "Islam Dan Modernitas: Tentang Transformasi Intelektual, Terj."
} 
memikirkan bagaimana meningkatkan mutu dari kekuatan Islam kembali. Akhirnya muncullah usaha-usaha pembaruan dalam berbagai bidang kehidupan manusia termasuk dalam bidang pendidikan di beberapa negara Islam ${ }^{19}$.

\section{Pengertian Pendidikan Islam}

Pendidikan Islam bagi Fazlur Rahman mencakup dua pengertian besar.

1. Pendidikan Islam dalam pengertian praktis, yaitu pendidikan yang dilaksanakan di dunia Islam seperti yang diselenggarakan di Pakistan, Mesir, Sudan, Saudi, Iran, Turki, Maroko, dan sebagainya, mulai dari pendidikan dasar sampai perguruan tinggi.

2. Pendidikan tinggi Islam yang disebut dengan intelektualisme Islam $^{20}$.

Intelektualisme Islam ini, merupakan penggunaan 'aql (intelektual, rasio), agar memperoleh pengetahaun dan pembelajaran dari fenomena alam yang ditemukan dalam kehidupan ${ }^{21}$. Intelektualisme Islam ini juga bisa dipahami bahwa seseorang yang bisa menafsirkan Islam dalam tema-tema (istilah-istilah) rasional dan ilmiah untuk memenuhi kebutuhan suatu masyarakat modern yang progresif. Keutamaan pendidikan Islam mestinya nampak dan mewarnai kehidupan manusia yang segar dan maju. Hal ini bisa terjadi ketika merespon berbagai penemuan dan perkembangan masa kini.

\section{Kerangka Berfikir Fazlur Rahman}

Proses ortodoks terjadi semenjak abad ke sepuluh telah menjadikan Islam sebagai "wacana resmi dan tertutup", kaidah berpikir dibatasi sedemikian rupa agar tidak "merusak" dan "mengganggu" kesucian Islam sebagai agama wahyu". Berdasarkan sejarah kelam di atas terhadap perkembangan intelektual dan kemajuan kaum muslimin dalam dunia pendidikan, keilmuan, keterbukaan berpikir, berjihad memperkaya diri dengan ilmu, penguasaan sains dan peradaban, yang pernah berada di tangan kaum ortodoks sampai sekarang masih banyak kelompok yang mewarisinya. Kemacetan intelektual muslim di berbagai negara di dunia saat ini termasuk Indonesia begitu sangat terasa dampaknya. Sikap tertutup atau ortodoks, sangat bertentangan dengan spirit esensi ajaran Islam yang merupakan anjuran pokok dari segala kehidupan untuk menemukan kebenaran dan kemajuan.

Konservatisme atau ketertutupan berlebihan yang pernah menguasai dunia Islam, begitu mereka menyingkirkan ilmu pengetahuan rasional. Dalam catatan sejarah dunia Islam, telah terjadi perlakuan berlebihan pada orang-orang rasionalis,

\footnotetext{
${ }^{19}$ H Muhaimin, Kontroversi Pemikiran Fazlur Rahman: Studi Kritis Pembaharuan Pendidikan Islam (Pustaka Dinamika, 1999).

${ }^{20}$ Sutrisno and terhadap Metode, "Epistemologi Dan Sistem Pendidikan."

${ }^{21}$ Hidayatullah, Intelektualisme Dalam Perspektif Neo-Modernisme.

${ }^{22}$ Ahmad Qodri Abdillah Azizy et al., Pemikiran Islam Kontemporer Di Indonesia (Kerjasama STAIN Ternate, Direktorat Perguruan Tinggi Agama Islam, Depag RI ..., 2005).
} 
yang banyak dihukum dan buku-bukunya dibakar, nantinya, para ulama Islam bahkan berusaha mengharamkan mesin cetak yang digunakan bangsa-bangsa muslim hingga tiga abad lamanya. Peradaban Islam akhirnya mengalami kemunduran besar dan kegagapan bahkan masih belum bangkit hingga sekarang ${ }^{23}$.

Muhaimin menjelaskan bahwa dalam rekaman sejarah, kemajuan pendidikan Islam banyak dipengaruhi oleh pemikiran rasional. Pemikiran tradisional yang mengabaikan peranan akal dan cenderung hanya pada hati, menimbulkan sikap fatalis di dalam diri umat Islam, sehingga metode pendidikan yang digerakkan hanya lebih pada pendidikan akhlak dibandingkan pendidikan intelektual. Mengulang suksesnya peradaban Islam pada masa lalu adalah hanya dengan cara sinergitas atau kombinasi pola pikir sehari-hari antara roh dan jasmani, atau antara akal dan wahyu $^{24}$.

Menurut Fazlur Rahman, kelemahan mendasar dari ilmu pengetahuan Islam, sebagaimana juga semua ilmu pengetahuan pra modern adalah konsepnya tentang ilmu pengetahuan. Berlawanan dengan sikap modern yang memandang ilmu pengetahuan sebagai suatu yang pada intinya harus dicari dan ditemukan oleh pikiran yang aktif, maka sikap zaman pertengahan adalah bahwa ilmu pengetahuan merupakan suatu yang harus diperoleh. Di dunia Islam pertentangan semakin tajam karena adanya pertentangan antara ilmu yang disampaikan atau ilmu tradisional (naql atau sami') di satu pihak dan ilmu rasional di pihak lain ${ }^{25}$.

Penulis memberi contoh bahwa, Gerakan Neo-Revivalis pasca modern, ketika dikaitkan dengan pendidikan, maka sekolah atau lembaga pendidikan Islam terdahulu, telah mengapresiasi perkembangan modern, namun masih dilihat merupakan 2 kutub. Modern dari barat, yang harus diterima secara selektif, dan mempertahankan nilai-nilai Islam sebagaimana yang dipahami selama ini, sehingga tampak seakan hanya bertahan saja dengan serangan perkembangan modern. Penerimaan pelajaran yang dikembangkan Barat disebutnya sebagai pelajaran umum, sementara pelajaran yang menekankan relijius, spiritual, ibadah dikategorikan pendidikan agama Islam. Hasil pemikiran pendahulu seperti ini, telah menghilangkan sebagian pesan-pesan, ajaran dan tradisi Islam.

\section{Kaitan antara Islam dan Pendidikan}

Hubungan Islam dan pendidikan bagi Fazlur Rahman, dalam bukunya, Islam and Modernity, berkomentar agak panjang lebar mengenai usaha-usaha untuk mengislamkan pendidikan umat Islam, yakni, "agar memasukkan konsep-konsep kunci tertentu mengenai Islam”. Kemudian Rahman menjelaskan bahwa strategi ini melibatkan dua aspek yang saling berhubungan:

\footnotetext{
${ }^{23}$ Eko Laksono, “Imperium III," Jakarta: Hikmah, 2006.

${ }^{24}$ Muhaimin, Pemikiran Dan Aktualisasi Pengembangan Pendidikan Islam.

${ }^{25}$ Fazlur Rahman, Islam and Modernity: Transformation of an Intellectual Tradition, vol. 15 (University of Chicago Press, 1984).
} 
a. membentuk mental anak didik dengan nilai-nilai Islam bagi kepentingan kehidupan pribadi dan kolektif.

b. Memasukkan nilai-nilai Islam ke dalam bidang-bidang studi yang lebih tinggi.

Dia menekankan perlunya "kerja intelektual untuk menjabarkan metafisika Islam berdasarkan al-Qur'an² ${ }^{26}$.

Menurut hemat penulis, bahwa di sini nampak Fazlur Rahman begitu terbuka dengan berbagai pengetahuan yang diproduksi manusia secara terus menerus, meski itu dari Barat. Yang keberanian Fazlur Rahman, justru mengakomodasi berbagai keilmuan, lalu memberikan nafas Islam. Ini yang bagi Rahman merupakan subtansi Islam, yang tak mesti tersimbolkan. Beda dengan An-Nahlawi yang menolak pengetahuan yang datang dari manusia untuk dijadikan landasan pendidikan. Pandangan An-Nahlawi ini, begitu meruntuhkan sendiri pernyataannya yang mengatakan bahwa pendidikan Islam itu harus sesuai fitrah manusia. Sementara ketika menolak atas penemuan-penemuan manusia sebagai fitrahnya yang makhluk berkarya, maka dengan itu juga An-Nahlawi mematikan fitrah dan kreativitas manusia.

\section{Sumber-sumber Pendidikan Islam}

Normatifitas suatu tradisi Islam diukur bila hal itu bersumber dari ajaran total al-Quran dan Sunnah dengan pola pemahaman yang benar. Pernyataan ini sealigus menolak peran-peran sejarah umat Islam dikatakan Islami bila hal itu hanya berdasarkan kepada kedua sumber tadi secara terpisah-pisah dan sepotongsepotong. Bagi Rahman, praktek-praktek aktual para sahabat, para tabi'in, perkembangan-perkembangan hukum, kalam, falsafat, sufi, maupun perkembanganperkembangan praktek "Islam" lainnya merupakan aspek historis yang kebenaran normatifnya mesti diuji aleh al-Qur'an dan Sunnah secara keseluruhan. Demikian pula perkembangan sains serta yurisprudensi merupakan bagian dari Islam historis yang tidak perlu dibuang begitu saja ${ }^{27}$.

Neo-modernis Islam Fazlur Rahman, sangat menekankan perlunya memperbarui Islam baik pada tingkat individual maupun pada tingkat komunitas. Mereka menempuh proses Islamisasi atau re-Islamisasi yang mulai dengan sumbersumber suci Islam, al-Qur'an dan Sunnah Nabi, tetapi juga mencakup yang terbaik dalam kultur-kultur lain ${ }^{28}$. Reformer atau neo-modernis kontemporer ini ingin melahirkan renaisans (nahdah) Islam yang mengikuti jalan kritis (terhadap) diri selektif yang serupa. Mereka membedakan antara wahyu Tuhan dan interpretasi

\footnotetext{
${ }^{26}$ Wan Mohd Nor Wan Daud and Wan Mohd Nor, "Filsafat Dan Praktik Pendidikan Islam Syed M. Naquib AlAttas," Bandung: Mizan, Translated by Hamid Fahmi et Al, 2003.

${ }^{27}$ Ahmad Tafsir et al., Cakrawala Pemikiran Pendidikan Islam, vol. 1 (Mimbar Pustaka: Media Tranformasi Pengetahuan, 2004).

${ }^{28} \mathrm{M}$ Pd I Kambali, "RELEVANSI PEMIKIRAN SYEKH AL-ZARNUJI DALAM KONTEKS PEMBELAJARAN MODEREN," Risâlah, Jurnal Pendidikan Dan Studi Islam 2, no. 1 (2015): 17-30.
} 
manusia, antara bagian hukum Islam yang abadi dan peraturan-peraturan yang merupakan gagasan-gagasan manusia yang dikondisikan oleh waktu dan tempat. ${ }^{29}$

\section{Metodologi Neo-Modernisme dalam Pembaruan Islam dan Pendidikan Islam}

\section{Sintesis Barat dan Islam}

Fazlur Rahman yang pertama kali menggunakan istilah Neo-Modernisme dalam suatu model yang sistematis ${ }^{30}$. Neo-Modernis menawarkan metodologi membangun tradisi sendiri dengan mengadopsi pengetahuan Barat, disintesiskan dengan semangat Islam. Barat sebagai pemenang metodologi era modern, dijadikan sebagai motivasi dan bantuan penelusuran untuk menemukan dan mengembangkan nilai-nilai modern dalam al-Qur'an, sunnah, dan warizan khazanah Islam klasik dengan cara kritik sejarah, menafsirkan atau menginterpretasi ulang, serta melakukan dekonstruksi (pembongkaran lalu penyusunan kembali).

Dengan begitu, maka tumbuh semangat baru bahwa sesungguhnya kemodernan itu adalah tradisi Islam, dengan penyadaran ini, umat diajak bersama membangun kemodernan sendiri yang berpotensi mengungguli Barat, dengan kelebihan dimiliki adalah bobotan spiritual yang menjadi landasan nilai. Kelompok neo-modernisme menyatakan bahwa Barat menderita karena krisis spiritual, yang dapat dibantu disembuhkan oleh Islam, sedangkan kaum Muslim modernis klasik seabad yang lalu kurang kritis terhadap Barat. ${ }^{31}$

\section{Gerakan Ganda (Double Movement)}

Fazlur Rahman menyebutkan, "a double movement from the present situation to the qur'anic times, then back to the present". Suatu gerakan ganda, gerakan dari situasi sekarang ke masa al-Qur'an diturunkan, kemudian gerakan kembali ke masa sekarang. Metode ini bisa dilakukan dengan:

1) Membawa problem-problem umat (sosial) untuk dicarikan solusinya pada al-Qur'an, atau

2) Memaknai al-Qur'an dalam konteksnya dan memproyeksikannya kepada situasi sekarang. berikut:

Mengenai pelaksanaan dari metode ini, Fazlur Rahman menguraikan sebagai

"Momen yang kedua yaitu memaknai al-Qur'an dalam konteks atau situasi turunnya, bertujuan sebagai pengoreksi hasil-hasil momen yang pertama", yaitu hasil-hasil dari pemahaman dan penafsiran.

\footnotetext{
${ }^{29}$ Tantowi Anwari dan Evi Rahmawati, ed., Pembaruan Pemikiran Islam Indonesia. ( Cet. I; Jakarta: Komunitas Epistemik Muslim Indonesia, 2011), h. 80-81.

${ }^{30}$ Gregory James Barton, The Emergence of Neo-Modernism: A Progressive, Liberal Movement of Islamic Thought in Indonesia: A Textual Study Examining the Writings of Nurcholish Madjid, Djohan Effendi, Ahmad Wahib and Abdurrahman Wahid, 1968-1980 (Monash University, 1995).

${ }^{31}$ Tantowi Anwari dan Evi Rahmawati, ed., Pembaruan Pemikiran Islam Indonesia, h. 83.
} 
Apabila hasil-hasil pemahaman dan penafsiran gagal dalam aplikasi sekarang, tentunya telah terjadi kegagalan menilai situasi sekarang dengan tepat atau kegagalan dalam memahami al-Qur'an. Sesuatu yang dulu bisa dan sungguhsungguh telah direalisasikan dalam tatanan spesifik di masa lampau, tidak mungkin tidak bisa direalisasikan dalam konteks sekarang ${ }^{32}$.

Supaya mudah memahami teori Fazlur Rahman, penulis menguraikan contohnya yang paling ringan dalam al-Qur'an diantaranya QS: Ali-Imran, 3: 110.

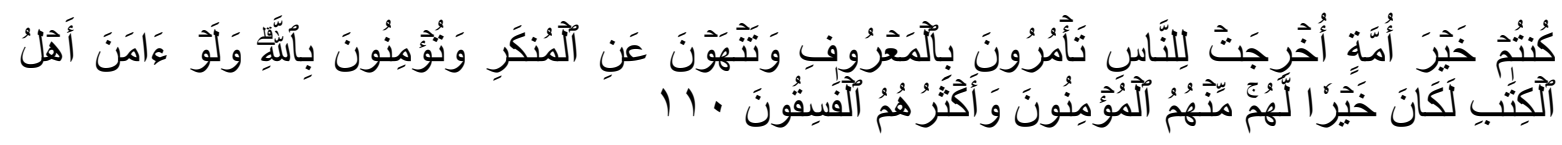

Terjemahan:

"Kamu (umat Islam) adalah umat terbaik yang dilahirkan untuk manusia, (karena kamu) menyuruh (berbuat) yang makruf, dan mencegah dari yang mungkar, dan beriman kepada Allah. Sekiranya Ahli Kitab beriman, tentulah itu lebih baik bagi mereka. Diantara mereka ada yang beriman, namun kebanyakan mereka adalah orang-orang fasik"33.

Bagi kalangan pemikir Islam ortodoks, mereka memahami ayat tersebut bahwa dirinya sudah menjadi umat terbaik di dunia ini. Bagi Rahman, pernyataan Qur'an ini harus di uji dengan pembuktian masa kini. Untuk semakin memudahkan maksud Rahman, penulis menguraikan pertanyaan untuk menguji pemahaman dan penafsiran kebanyakan orang selama ini terhadap ayat itu:

1. Apakah umat beragama Islam sudah pasti menjadi terbaik dalam dunia ini?

2. Kalau memang terbaik, mengapa umat Islam harus menderita berabad-abad sampai saat ini dalam penindasan penjajahan Barat, baik secara fisik seperti yang dirasakan Pelestina, Mesir, Yaman, Suriah, dan negara lainnya yang berpenduduk banyak Islam. Dari segi non fisik seperti di Indonesia dan negara muslim lainnya, yaitu umat Islam dikalah dalam pemikiran dan gagasan menciptakan masyarakat adil makmur?

3. Mengapa umat Islam di dunia ini terutama di Indonesia masih banyak dalam kemiskinan dan kebodohan, padahal umat Islamnya banyak?

4. Mengapa pendidikan Islam di Indonesia ini belum mampu menciptakan pemimpin umat, bangsa dan negara, serta belum mampu mencetak pemikir dan ilmuan monumental?

5. Mengapa ilmu dan teknologi yang dikuasainya lemah dan sedikit mempunyai prestasi?

6. Mengapa umat Islam paling banyak yang menjadi komsumtif dari kreatifitas bangsa lain atau dari non muslim?

\footnotetext{
${ }^{32}$ Sutrisno and terhadap Metode, "Epistemologi Dan Sistem Pendidikan."

${ }^{33}$ R I Kementerian Agama, “Al-Qur'an Dan Terjemahnya," Jakarta: Sinergi Pustaka Indonesia, 2012.
} 
7. Mengapa pendidikan Islam Indonesia gagal menanamkan nilai-nilai dan moral pada umat?, dan masih banyak pertanyaan bagi implikasi keberagamaan kita selama ini.

Bagi Rahman, berbagai pertanyaan di atas sebagai fakta, membuka pikiran dan mata batin kita supaya menghayati kontradiksi antara wahuyu ideal yaitu alQur'an dengan kenyataan sekarang. Karena kita sebagai umat Islam yang yakin kebenaran al-Qur'an secara otentik, maka bisa bisa dipastikan kitalah yang salah menafsirkan QS: Ali-Imran, ayat 110 itu, sehingga kita mengalami anomali dan kegagapan dalam perkembangan kontemporer.

QS: Ali-Imran, ayat 110 itu, merupakan gambaran Allah atas situasi dan kemampuan umat terdahulu yang berhasil menjadi umat terbaik di zamannya. Kita di era kontemporer ini, dengan bentangan waktu sekitar 1400 tahun yang lalu ayat itu, merupakan suatu keanehan besar ketika kita tidak berupaya meninjau ulang pemahaman baru terhadap informasi ayat tersebut. Pemikiran Islam yang tertutup dan tekstual, menyebabkan pemahaman dalam pendidikan Islam pun juga ikut tertutup dan statis. Itu karena, telah puas atas produk pemikiran manusia terdahulu, tanpa ada keberanian dan inisiatif untuk menemukan dan menafsirkan semangat ayat al-Qur'an berdasarkan situasi dan kondisi kekinian.

Contoh yang ke dua: QS: (An-Nisa; 4), yaitı1.

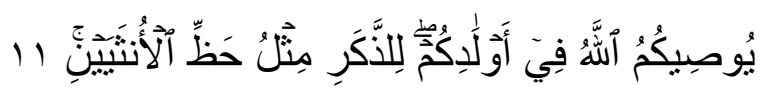
11. Allah mensyari'atkan (mewajibkan) kepadamu tentang (pembagian warisan untuk) anak-anakmu, (yaitu) bahagian seorang anak lelaki sama dengan bagian dua orang anak perempuan ${ }^{34}$.

Bagi Rahman, ayat waris ini telah banyak orang keliru memahami maknanya karena mengukurnya dari segi kuantitas. Padahal ayat ini turun sebagai solusi atas kondisi masyarakat pra Islam yang tidak memperlakukan manusia secara adil. Hemat penulis, karena fitrah manusia menginginkan keadilan, maka wajar ketika banyak masyarakat di suatu tempat yang tidak mengikuti anjuran ayat al-Qur'an di atas karena merasa tidak adil, contoh kasus di Desa Dusun Baru Rantau Panjang Kecamatan Tabir Jambi, sangat berbeda dengan sistem Hukum Waris Islam. Yakni sistem waris yang selama ini digunakan oleh masyarakat setempat dalam menyelesaikan harta warisan orang yang telah meninggal dunia adalah dengan menggunakan Sistem Waris Adat 1:2 dengan perolehan lebih banyak untuk ahli waris perempuan.

Dalam sistem waris tersebut jika seorang laki-laki mendapatkan 1, maka ahli waris perempuan mendapatkan 2. Namun demikian perbedaan-perbedaan tersebut tidak perlu diperdebatkan. Sebab, prinsip pembagian warisan dalam Islam dimaksudkan untuk pencapaian adil dan keadilan, bagi masyarakat yang setempat

\footnotetext{
${ }^{34}$ Kementerian Agama.
} 
yang menggunakan sistem pembagian harta warisan berdasarkan Hukum Adat, tidak ada yang merasa dirugikan.

Dengan memperhatikan Kaidah Ushul Fiqih yang menunjukkan bahwa "kemungkinan terjadi perubahan hukum dikarenakan perubahan keadaan dan suasana dari waktu ke waktu", dan juga kaidah yang lain yaitu "menarik maslahat dan menolak mafsadat", maka dibenarkan masyarakat di daerah tersebut melaksanakan Sistem Waris Adat 1:2, sebab beban dan tanggung jawab seorang perempuan dan laki-laki dalam kaitannya mencari nafkah untuk menghidupi keluarga adalah sama. ${ }^{35}$

Megenai ayat ini, Fazlur Rahman melakukan perenungan dan eksplorasi mendalam, dan sampai pada keyakinan bahwa, kemungkinan besar selama ini telah disalah pahami makna ayat ini, sehingga menyebabkan berabad-abad lamanya perempuan terpinggirkan dari segala sektor termasuk pada kesempatan menuntut ilmu, Perempuan dipersepsi tugasnya hanya tinggal di rumah, tidak diperhitungkan dalam masyarakat, dan selalu dialamatkan pada dirinya sumber kemaksiatan. Berdasarkan fenomena ini, Fazlur Rahman sangat resah dan merasa ada yang janggal, karena temuan Rahman dalam semangat petunjuk al-Qur'an adalah keadilan sosial.

Maka Fazlur Rahman mencoba memakai teori "Double Movementnya"atau penulis sering istilahkan teori (Bolak-Balik Sejarah). Dengan cara menganjurkan menulusuri keadaan perempuan di masa sebelum Islam yang dibawa Muhammad, saw. Rahman menggunakan beberapa pakar sejarah baik dari Timur maupun Barat. Yang mengejutkan bagi Fazlur Rahman adalah, bahwa ternyata kondisi perempuan di Timur Tengah dan Eropa sama kondisinya waktu itu, dijadikan makhluk yang rendah dan tak berdaya atas dominasi laki-laki. Dari hasil temuan Rahman, ternyata berbagai macam yang dijumpai dalam sejarah hubungan laki-laki dan perempuan di antaranya.

a. Suatu rumah tangga ingin keturunan lebih baik, isterinya dia pinjamkan ke orang lain.

b. Satu perempuan bergabung dengan sepuluh orang laki-laki, kalau dia melahirkan, baru dia pilih salah satu laki-laki yang dia suka.

c. Pelacuran.

d. Bayi perempuan dibunuh.

e. Isteri diwarisi oleh anaknya, atau jadi objek waris.

f. Poligami tanpa batas.

g. Perempuan jadi pelampiasan nafsu, dan lain-lain.

Berdasarkan fakta ini, maka para peneliti Barat dan Timur termasuk Fazlur Rahman, sepakat bahwa, ternyata perempuan di masa sebelum Islam, berada pada -o derajat, atau di bawah titik Nol. Artinya, perempuan merupakan objek.

\footnotetext{
${ }^{35}$ http://library.walisongo.ac.id/digilib/gdl.php?mod=browse\&op=read\&id=jtptiain-gdl-munfaati21-4034
} 
Di sinilah Fazlur Rahman menyimpulkan bahwa, ternya makna QS. An-Nisa ayat 11, bukan dari segi kuantitasnya 2:1, tapi ayat ini turun sebagai penolong terhadap perempuan untuk diperlakukan secara adil. Bagi Rahman, perempuan sebelumnya jadi objek, sekarang menjadi subjek yang menerima 1 bagian warisan. Strategi ini dilakukan Allah secara perlahan, supaya umat waktu itu mudah menerima aturan Allah mengangkat harkat dan martabat manusia pada kesetaraan dan kemuliaan. Rahman melanjutkan bahwa, perempuan waktu itu juga di angkat 2 digit. Itu langkah pencapaian yang luar biasa.

Kemudian diturunkan ayat tentang perintah memberi mahar pada perempuan yang dinikahi, QS. An-Nisa Ayat 4

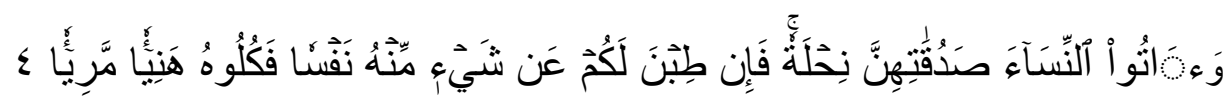

4. Berikanlah maskawin (mahar) kepada wanita (yang kamu nikahi) sebagai pemberian dengan penuh kerelaan. Kemudian jika mereka menyerahkan kepada kamu sebagian dari maskawin itu dengan senang hati, maka makanlah (ambillah) pemberian itu (sebagai makanan) yang sedap lagi baik akibatnya, ${ }^{36}$

Kemudian diwajibkan laki-laki menafkahi isterinya, QS. An-Nisa Ayat 34

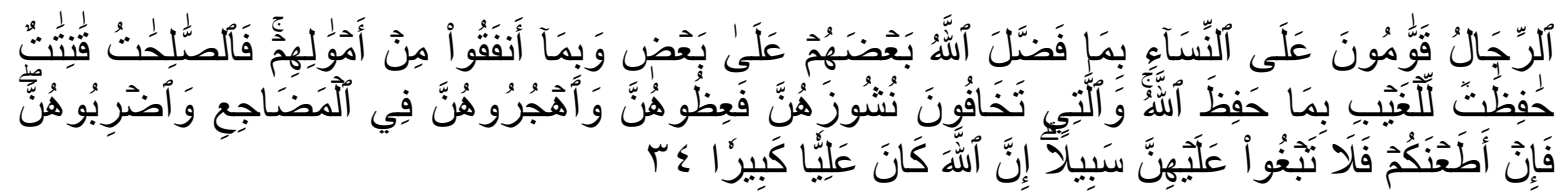

34. Kaum laki-laki itu adalah pemimpin bagi kaum wanita, oleh karena Allah telah melebihkan sebahagian mereka (laki-laki) atas sebahagian yang lain (wanita), dan karena mereka (laki-laki) telah menafkahkan sebagian dari harta mereka. Sebab itu maka wanita yang saleh, ialah yang taat kepada Allah lagi memelihara diri ketika suaminya tidak ada, oleh karena Allah telah memelihara (mereka). Wanita-wanita yang kamu khawatirkan nusyuznya, maka nasehatilah mereka dan pisahkanlah mereka di tempat tidur mereka, dan pukullah mereka. Kemudian jika mereka mentaatimu, maka janganlah kamu mencari-cari jalan untuk menyusahkannya. Sesungguhnya Allah Maha Tinggi lagi Maha Besar. ${ }^{37}$

Ketika mengaitkan ayat ini, maka nampak sekali bahwa justru semua ayat di atas merupakan keberpihakan terhadap perempuan.

Kalaupun mau berbicara dengan ukuran kuantitas, dengan cara 2:1. Laki-laki 2 sedangkan Perempuan 1. Sebagaimana pendapat sebagian besar kelompok selama ini yang tekstual, karena menganggap laki-laki punya tanggungan yang besar menafkahi isteri dan anaknya, maka rumusnya begini dari sistematika Ayat:

Jika harta warisan 30, berarti, laki-laki dapat 20, sedangkan perempuan dapat 10. Lalu laki-laki di wajibkan memberi mahar pada perempuan, anggaplah 5 dari

\footnotetext{
${ }^{36}$ Kementerian Agama, "Al-Qur'an Dan Terjemahnya."

${ }^{37}$ Kementerian Agama.
} 
hasil warisan tadi yang 20, lalu laki-laki diwajibkan lagi menafkahi isteri dan anaknya, paling sedikit 15. Maka, semua harta warisan itu berkumpul pada perempuan sebanyak 30. Begitu banyaknya kebaikan yang terungkap dalam memaknai ayat-ayat al-Qur'an jika kita mau terbuka untuk menelusuri pesan dasar dan inti semangat ajaran Islam.

Sebagaiman pendapat Rahman, bahwa perintah-perintah al-Qur'an muncul tidak dalam suatu kevakuman, tetapi selalu turun sebagai solusi terhadap masalahmasalah aktual. Latar belakang situasional ini, yang disebut "sebab-sebab pewahyuan". ${ }^{8}$

Demikianlah contoh paling ringan manfaat dari maksud teori Gerak-Ganda Fazlur Rahman. Fazlur Rahman menyarankan, pertama gerakan dari penangananpenanganan kasus konkrit oleh al-Qur'an dengan memperhitungkan kondisi-kondisi sosial yang relevan pada waktu itu kepada prinsip-prinsip umum tempat keseluruhan ajaran al-Qur'an berpusat. Kedua, dari peringkat umum ini, harus dilakukan gerakan kembali kepada legislasi yang spesifik dengan memperhitungkan kondisi-kondisi sosial yang ada sekarang. Kemudian selanjutnya Fazlur Rahman menawarkan metode berpikir yang terdiri atas dua gerakan, yaitu: pertama, metode berpikir dari yang khusus kepada yang umum (induktif), dan kedua, metode berpikir dari yang umum kepada yang khusus (deduktif). ${ }^{39}$

Sebagaimana dalam metode berpikir yang pertama, Rahman melibatkan pemahaman terhadap prinsip al-Qur'an dengan mana Sunnah merupakan bagian organisnya. Sektor sosial perintah-perintah al-Qur'an memiliki suatu latar belakang situasional, sebagaimana pewahyuan al-Qur'an sendiri yang memiliki latar belakang religio-sosial yang amat kongkret dalam politeisme dan disekuilibrium sosioekonomi masyarakat Makkah pada awal Islam.

Sementara dalam gerakan pemikiran kedua, Rahman menguraikan bahwa metode berpikir dari yang umum kepada yang khusus. Kumpulan prinsip yang diperoleh dari al-Qur'an lewat cara gerakan pemikiran yang pertama, harus diterapkan terhadap masyarakat Muslim dalam konteks dewasa ini. Sebagaimana dengan latar belakang ajaran al-Qur'an yang harus dikaji untuk memperoleh prinsipprinsip umum al-Qur'an, maka situasi kontemporer juga harus dikaji untuk diambil darinya prinsip-prinsip tentang penerapan hukum terhadap situasi tersebut. ${ }^{40}$

\section{Tradisi Pemahaman dalam Islam dan Pendidikan Islam}

Tradisi dalam Islam menurut Fazlur Rahman harus dipisahkan antara tradisi ideal dengan tradisi yang murni historis. Dalam kata lain Islam terdiri dari "Islam Normatif" dan "Islam Historis". Tradisi ideal merupakan nilai-nilai yang tidak terbatas dengan ruang dan waktu atau melampaui batas-batas historisnya dan

\footnotetext{
${ }^{38}$ Sutrisno and terhadap Metode, "Epistemologi Dan Sistem Pendidikan."

${ }^{39}$ Sutrisno and terhadap Metode.

${ }^{40}$ Sutrisno and terhadap Metode.
} 
penilaian benar atau salahnya adalah al-Qur'an dan Sunnah yang dipahami secara komprehensif dan integral. Sedangkan yang dimaksud dengan Islam historis adalah segala hal yang dilakukan kaum muslimin dan dianggap atau dipahami benar sebagai hasil pemahamannya terhadap al-Qur'an dan sunnah. Tradisi ideal merupakan kristalisasi nilai-nilai yang dihasilkan dari peristiwa-peristiwa atau pernyataan-pernyataan, sedangkan tradisi historis berkait pemahamannya dengan Islam historis. ${ }^{41}$

\section{Tujuan Pendidikan Islam menurut Fazlur Rahman}

Menurut Rahman, bahwa perhatian sentral al-Qur'an adalah manusia, bukan Tuhan. Istilah lain, bahwa pendidikan Islam sumbernya adalah al-Qur'an, maka rumusan pendidikan Islam pun harus berpihak pada kemanusiaan. Itulah salah satu sebab Fazlur Rahman tampak tidak tertarik untuk menyelesaikan kontroversi antara para filosof, penganut Mu'tazilah, Mutakallimun, dan kaum sufi dalam masalahmasalah yang mendasar, seperti mengenai hakikat Tuhan. Baginya, esensi Islam adalah homosentris, bukan teosentris. ${ }^{42}$ Pandangan Rahman sejalan juga dengan Muhammad Iqbal bahwa tujuan pendidikan adalah manusia. ${ }^{43}$

\section{Keutamaan pembaruan dalam pendidikan Islam}

Neo-modernis Islam Fazlur Rahman, sangat menekankan perlunya memperbarui Islam baik pada tingkat individual maupun pada tingkat komunitas. Mereka menempuh proses Islamisasi atau re-Islamisasi yang mulai dengan sumbersumber suci Islam, al-Qur'an dan Sunnah Nabi, tetapi juga mencakup yang terbaik dalam kultur-kultur lain. Reformer atau neo-modernis kontemporer ini ingin melahirkan renaisans (nahdah) Islam yang mengikuti jalan kritis (terhadap) diri selektif yang serupa. Mereka membedakan antara wahyu Tuhan dan interpretasi manusia, antara bagian hukum Islam yang abadi dan peraturan-peraturan yang merupakan gagasan-gagasan manusia yang dikondisikan oleh waktu dan tempat. ${ }^{44}$

Fazlur Rahman sangat dibutuhkan sebagai sosok seseorang yang bisa menafsirkan Islam dalam tema-tema (istilah-istilah) rasional dan ilmiah untuk memenuhi kebutuhan suatu masyarakat modern yang progresif. Keutamaan pendidikan Islam mestinya nampak dan mewarnai kehidupan manusia yang segar dan maju. Hal ini bisa terjadi ketika merespon berbagai penemuan dan perkembangan masa kini. Sejalan dengan berbagai uraian di atas, Fazlur Rahman

\footnotetext{
${ }^{41}$ Rahman, Islam and Modernity: Transformation of an Intellectual Tradition.

42 Daud and Nor, "Filsafat Dan Praktik Pendidikan Islam Syed M. Naquib Al-Attas."

${ }^{43}$ Rahman, "Islam Dan Modernitas: Tentang Transformasi Intelektual, Terj."

${ }^{44}$ Tantowi Anwari dan Evi Rahmawati, ed., Pembaruan Pemikiran Islam Indonesia. ( Cet. I; Jakarta: Komunitas Epistemik Muslim Indonesia, 2011), h. 80-81.
} 
sampai pada satu tesis bahwa secara eksplisit dasar ajaran Alquran adalah moral yang memancarkan titik beratnya pada monoteisme dan keadilan sosial. ${ }^{45}$

\section{Relevansi Pemikiran Pendidikan Islam Fazlur Rahman Dalam Konteks Pendidikan Islam di Indonesia.}

Relevansi pemikiran Fazlur Rahman dalam konteks Indonesia begitu gencar dan sangat diapresiasi. Apalagi di Indonesia begitu dijumpai tokoh-tokoh NeoModernis yang banyak berpengaruh terhadap berbagai bidang dan berbagai disiplin ilmu. Di antara tokoh-tokoh Neo-Modernis Indonesia juga merupakan murid terbaik Fazlur Rahman, yaitu Nurcholish Madjid dan Syafii Maarif.

Nurcholish Madjid menyatakan bahwa, memang umat Islam sekarang sedang ketinggalan zaman di bidang sains dan teknologi, tetapi yang sangat penting bahwa Islam membuktikan kesatuan organik dan harmonis antara ilmu-pengetahuan dan iman, sehingga kebahagiaan yang bisa dihasilkan senyawa lahir dan batin. Dengan demikian, umat Islam harus optimis terhadap zaman modern, sains dan tekhnologi, ateisme, deisme, dan sebagainya, sebab sistem ajaran Islam, bila dipahami dan dijalankan secara benar, memiliki tatacara melekat untuk menangkal segi-segi negatif itu semua, dan mempunyai potensi untuk memberi itu semua bimbingan yang benar. ${ }^{46}$

Pemikiran pendidikan Islam yang tertutup, menyebabkan pemahaman dan kebiasaan selalu mewarnai tradisi pendidikan formal maupun non formal samasama cenderung statis, telah puas atas produk pemikiran manusia terdahulu dan masa kini, tanpa ada keberanian dan inisiatif untuk menemukan dan mencari juga hal terbaru dalam dinamika keilmuan. Kebanyakan kita jadi individu yang copy paste, klise, selalu berpatokan dari pengetahun yang sudah dianggap mapan selama ini. Ketika ada yang berbeda kita menyebutnya abnormalitas, dianggap aneh, bid'ah, menyimpang, menyeleweng, padahal yang terbaik adalah keberanian memunculkan pikiran dan ide-ide yang canggih, lebih kreatif, baru dan segar.

Ketika Islam tradisional mengkritik kehidupan modernis, kemudian bermaksud menawarkan solusi dengan kembali pada produk pemikiran masa silam, maka menjelma sikap yang tertutup atas kemajuan masyarakat kontemporer. Begitu juga dengan sikap Islam modernis, yang cenderung mengabaikan khazanah intelektual terdahulu, dengan semata-mata lebih pada pemahaman terhadap teks alQur'an lalu mengaitkan dengan masa modern atau perkembangan ke depannya.

Jika Islam tradisional memenjarakan wahyu al-Qur'an untuk tidak dibiarkan menyapa realitas masa kini, dan tidak menerima interpretasi terus-menerus atas temuan-temuan kemajuan manusia, maka akan selalu nampak kontradiksi antara wahuyu ideal yaitu al-Qur'an dengan kenyataan kontemporer. Begitu juga dengan sikap modernis yang mengabaikan berbagai keberhasilan tokoh-tokoh Muslim

\footnotetext{
${ }^{45}$ Fazlur Rahman, “Islam,(Terj.) Senoaji Saleh, Dari Judul Asli Islam,” Jakarta, Bina Aksara, 1987.

${ }^{46}$ Nurcholish Majid, Islam Agama Peradaban: Membangun Makna Dan Relevansi Doktrin Islam Dalam Sejarah (Paramadina, 1995).
} 
terdahulu, padahal begitu banyak karya dan hasil yang menggembirakan telah dibuktikan. Ketika kedua hal ini tidak ada perjumpaan, maka umat akan semakin mengalami kegagapan dan anomali di masa mendatang. Pemikiran perjumpaan inilah merupakan usaha proyek pemikiran Fazlur Rahman yang menjadi epistemologi dan landasan pembaruannya, yang dia sebut Neo-Modernis.

Dengan demikian, jargon yang dikumandangkan oleh Neo-Modernis menggarisbawahi perlunya para pemikir, pemerhati, dan pengembangan pendidikan yang dilakukan pada era kenabian dan sahabat serta oleh para ulama terdahulu (pasca salafi) sebagai pengalaman mereka dan dalam konteks ruang dan zamannya, untuk selanjutnya perlu dilakukan uji falsifikasi, agar ditemukan relevan atau tidaknya dengan konteks sekarang dan yang akan datang. Hal-hal yang dipandang relevan akan dicarikan alternatif lainnya atau dilakukan rekonstruksi tertentu dalam konteks pendidikan masyarakat Muslim kontemporer. ${ }^{47}$

Fazlur Rahman sebagai juru bicara Neo-Modernis yang serius dan produktif, ia memberikan sumbangan yang berarti bagi pembicaraan mutakhir tentang citra Islam dengan berbagai temuan dan karya-karyanya. Dua tokoh intelektual Mislim yang pernah menjadi murid dan lama berjumpa dengan Fazlur Rahman adalah Syafii Maarif mengatakan bahwa pada diri Rahman "berkumpul ilmu seorang alim yang alim dan ilmu seorang orientalis yang paling beken” Nurcholis Madjid berkomentar bahwa Rahman seorang yang berpenampilan sederhana, lugu dan sepi ing pamrih tetapi seorang guru yang banyak membangkitkan ilham dan berkemampuan amat cermat membaca khazanah klasik Islam, seorang intelektual demokratis, berkemampuan berbagai bahasa. Rahman juga seorang pemikir intelektual yang mencengangkan, kontroversi baginya adalah suatu bagian dari konsekuensi kreativitas keilmuan yang sulit dihindari. ${ }^{48}$

Menyempitnya lapangan ilmu pengetahuan umum karena tiadanya pemikiran umum dan sains-sains kealaman, menyebabkan kurikulum menjadi terbatas pada ilmu-ilmu keagamaan murni dengan gramatika dan kesusasteraan sebagai alat-alatnya yang diperlukan. ${ }^{49}$

Menurut Rahman, sebagian dari penjelasan mengenai kemerosotan gradual standar-standar akademis selama berabad-abad terletak pada fakta bahwa:

Jumlah buku yang tercantum dalam kurikulum sedikit sekali, waktu yang diperlukan untuk belajar juga terlalu singkat bagi si murid untuk bisa menguasai bahan-bahan yang "kenyal". Sehingga seringkali sulit dipahami mengenai segi-segi tinggi ilmu keagamaan pada usia yang relative muda dan belum matang. Ini menjadikan belajar lebih banyak bersifat studi tekstual buku-buku dari pada memahami pelajaran yang bersangkutan, yang pada gilirannya lebih mendorong hafalan dari pada pemahaman yang sebenarnya. ${ }^{50}$

\footnotetext{
${ }^{47}$ Muhaimin, Pemikiran Dan Aktualisasi Pengembangan Pendidikan Islam.

${ }^{48}$ Abdulfatah Idris, "Studi Pemikiran Fazlur Rahman Tentang Hadis-Hadis Prediktif Dan Teknis" (IAIN Walisongo, 2012).

${ }^{49}$ Rahman, Islam and Modernity: Transformation of an Intellectual Tradition.

${ }^{50}$ Muhaimin, Kontroversi Pemikiran Fazlur Rahman: Studi Kritis Pembaharuan Pendidikan Islam.
} 
Lebih lanjut, Fazlur Rahman dalam bukunya, Islam and Modernity, berkomentar agak panjang lebar mengenai usaha-usaha untuk mengislamkan pendidikan umat Islam, yakni, "agar memasukkan konsep-konsep kunci tertentu mengenai Islam”. Kemudian Rahman menjelaskan bahwa strategi ini melibatkan dua aspek yang saling berhubungan pertama, membentuk mental anak didik dengan nilai-nilai Islam bagi kepentingan kehidupan pribadi dan kolektif; dan kedua memasukkan nilai-nilai Islam ke dalam bidang-bidang studi yang lebih tinggi. Dia menekankan perlunya "kerja intelektual untuk menjabarkan metafisika Islam berdasarkan al-Qur'an."

Berdasarkan keresahan Rahman di atas, inipula yang terjadi di Indonesia, banyakya pendidikan Islam atau pesantren ditinggalkan karena ketakutan paksaan menghafal. Padahal hemat penulis, bahwa desain kurikulum untuk menghafal mestinya di bebaskan pada murid, mau pilih yang mana dengan menyiapkan berbagai jurusan yang lain yang bisa memperkokoh keilmuan para murid dan bakatnya. Misal, membuka jurusan ahli tafsir alqur'an, hadis. Pemikir Islam, Pemikir Pendidikan Islam, dan lainnya.

Menurut Fazlur Rahman, dia tidak sepakat kalau lembaga pendidikan berada di bawah kekuasaan pemerintah, karena akan menjadi terkungkung, Rahman lebih menawarkan harapan pada lembaga pendidikan swasta. Konsep Fazlur Rahman ini, bagaimana dengan kondisi di Indonesia, kita membuka mata bahwa, lembaga pendidikan negeri, kurikulum dan pengajarannya telah banyak diatur oleh peguasa, dan lembaga pendidikan swasta juga masih banyak kekurangan. Pemangkasan kreativitas siswa dan mahasiwa begitu terasa dengan paksaan untuk bungkam, menutup mata terhadap kezaliman yang terjadi di sekitar kita. Perlawanan akan mengikat kita pada ancaman dikeluarkan. Sedangkan di swasta, memang diberi kewenangan banyak mendesain kurikulum, namun pelaksanaan, pengajaran dan tenaga pengajarnya masih belum bisa optimal disebabkan berbagai kesibukan.

Lantas bagaimana solusi yang kira-kira bisa ditawarkan sebagai solusi pendidikan. Masyarakat Indonesia harus berusaha merubah paradigma tentang orientasi pendidikan. Dan pemerintah hendaknya berupaya mengoptimalkan kesejahteraan orang yang mengabdikan dirinya pada pendidikan, di negara maju dan super power, mereka sangat diperhatikan keilmuannya. Sehingga banyak pemikir ternama yang rata-rata dari eropa, dikarenakan kemerdekaan berpikir telah dikerjakan secara serius. Beda ketika dibandingkan di Indonesia, sedikit sekali pemikir ternama yang muncul, dikarenakan banyaknya bidang lain yang mereka harus kerjakan demi mencukupi kebutuhan diri dan keluarganya. Itu sangat menyita waktunya yang semestinya digunakan banyak berkarya dan produktif. Jika pemerintah mengapresiasi berbagai disiplin ilmu yang ditempuh generasi dengan berbagai standar prosedur yang relevan, maka paradigma masyarakat akan berubah dan akan menjadi produktif.

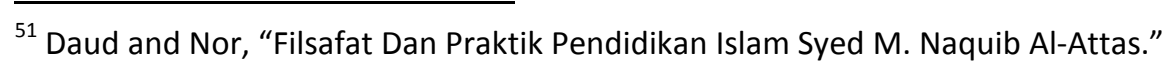




\section{Simpulan}

1. Benang merah perbedaan dan persamaan rumusan pendidikan Islam Fazlur Rahman dengan pemikir lainnya, terletak pada pemahamannya yang beda mengenai tujuan, konsep dan metode pendidikan Islam.

2. Setidaknya pemikiran Fazlur Rahman dapat membantu kita menelusuri konteks atau kondisi historis waktu itu di mana titik berangkat membangun pemikirannya, yaitu kondisi yang umat Islam sendiri waktu itu telah terpesona pada kemajuan modern, sehingga banyak mengabaikan karya intelektual Islam terdahulu, dan mempercayai sepenuhnya metode Barat dianggap terbaik. Maka pemisahan antara pendidikan umum dan pendidikan Islam waktu itu baginya tidaklah mengapa. Karena Barat menjadi pemenang kemajuan pendidikan, telah diterapkan di sekolahsekolah dunia muslim.

3. Materi Islam waktu itu banyak disekulerkan, dengan mengganti namanya menjadi nama yang lain, misal al-haya (ilmu tentang kehidupan) diganti jadi biologi, geografi, fisika, kimia dan lain-lain, yang sebelumnya semua terintegrasi dalam materi Islam. Bagi kalangan Muslim yang kritis mempertahankan kemurnian Islam, dengan beranggapan bahwa ketika ini berlarut maka krisis moral dan keimanan umat Islam bisa semakin terkikis. Landasan berpikir demikian membuatnya begitu menolak pemahaman Barat dan sangat menghindari, hal ini semakin memperkuat dikotomi pendidikan Islam dan Barat.

4. Ditengah kondisi pendidikan dunia Islam begitu belum bisa mengungguli Barat, Fazlur Rahman berpikir keras bagaimana bisa membangkitkan umat Islam dengan membangun pikiran-pikiran segar, sampai pada tawaran bahwa kemajuan modern harus diadakan perjumpaan episentrum dengan khazanah intelektul klasik. Kemudian nantinya teori Fazlur Rahman sangat terkenal yaitu "Double Movement" (gerakan ganda). Tujuan dan pesan dasar Al-Qur'an dan pendidikan Islam bagi Fazlur Rahman adalah untuk manusia, yang termanifestasi pada moral dan keadilan sosial.

5. Fazlur Rahman dalam menguraikan salah satu pesan dasar al-Qur'an, dijumpai pada pendapatnya bahwa semangat al-Qur'an adalah keadilan. 


\section{DAFTAR PUSTAKA}

Anwari Tantowi dan Rahmawati Evi, ed., Pembaruan Pemikiran Islam Indonesia. Cet.

I; Jakarta: Komunitas Epistemik Muslim Indonesia, 2011.

Azizy, Ahmad Qodri Abdillah, Adnan Mahmud, Sahjad M Aksan, and M Adib Abdushomad. Pemikiran Islam Kontemporer Di Indonesia. Kerjasama STAIN Ternate, Direktorat Perguruan Tinggi Agama Islam, Depag RI ..., 2005.

Barton, Gregory James. The Emergence of Neo-Modernism: A Progressive, Liberal Movement of Islamic Thought in Indonesia: A Textual Study Examining the Writings of Nurcholish Madjid, Djohan Effendi, Ahmad Wahib and Abdurrahman Wahid, 1968-1980. Monash University, 1995.

Daud, Wan Mohd Nor Wan, and Wan Mohd Nor. "Filsafat Dan Praktik Pendidikan Islam Syed M. Naquib Al-Attas.” Bandung: Mizan, Translated by Hamid Fahmi et Al, 2003.

FAUZAN, IBNUDIN. “THE THINKING OF CONTEMPORARY ISSUES IN ISLAMIC WORLD (PEMIKIRAN ISU-ISU KONTEMPORER DALAM DUNIA KEISLAMAN)." Al-Afkar, Journal For Islamic Studies 3, no. 1 (2019): 35-47.

Hidayatullah, Syarif. Intelektualisme Dalam Perspektif Neo-Modernisme. Tiara Wacana Yogya, 2000.

Hamsah, Muhammad. Liberalisme Mendobrak Pemikiran Ortodoks (Kritik Islam Liberal Terhadap Pemikiran Pendidikan Islam Ortodoks Di Indonesia. Makassar: Skripsi UIN Alauddin, 2015.

Idris, Abdulfatah. "Studi Pemikiran Fazlur Rahman Tentang Hadis-Hadis Prediktif Dan Teknis." IAIN Walisongo, 2012.

Kambali, M Pd I. "RELEVANSI PEMIKIRAN SYEKH AL-ZARNUJI DALAM KONTEKS PEMBELAJARAN MODEREN.” Risâlah, Jurnal Pendidikan Dan Studi Islam 2, no. 1 (2015): 17-30.

Kementerian Agama, R I. "Al-Qur'an Dan Terjemahnya.” Jakarta: Sinergi Pustaka Indonesia, 2012.

Laksono, Eko. “Imperium III.” Jakarta: Hikmah, 2006.

Majid, Nurcholish. Islam Agama Peradaban: Membangun Makna Dan Relevansi Doktrin Islam Dalam Sejarah. Paramadina, 1995.

Moleong, Lexy J, and Tjun Surjaman. Metodologi Penelitian Kualitatif. Penerbit PT Remaja Rosdakarya, 1991.

Muhaimin. Pemikiran Dan Aktualisasi Pengembangan Pendidikan Islam. Rajawali Pers, 2011.

Muhaimin, H. Kontroversi Pemikiran Fazlur Rahman: Studi Kritis Pembaharuan Pendidikan Islam. Pustaka Dinamika, 1999.

Munir, Asep Arsyul. "AGAMA, POLITIK DAN FUNDAMENTALISME." Al-Afkar, Journal For Islamic Studies 1, no. 1 (2018): 149-69. 
Nata, Abuddin. Pemikiran Pendidikan Islam E Barat. PT RajaGrafindo Persada, 2012. Patilima, Hamid. "Metode Penelitian Kualitatif (Edisi Revisi).” Bandung: Penerbit Alfabeta, 2011.

Rahman, Fazlur. “Islam,(Terj.) Senoaji Saleh, Dari Judul Asli Islam.” Jakarta, Bina Aksara, 1987.

- - - Islam and Modernity: Transformation of an Intellectual Tradition. Vol. 15. University of Chicago Press, 1984.

_-_. "Islam Dan Modernitas: Tentang Transformasi Intelektual, Terj." Ahsin Muhammad, Bandung: Pustaka 1 (1985).

Sugiyono. Metode Penelitian Pendidikan:(Pendekatan Kuantitatif, Kualitatif Dan $R \mathcal{E}$ D). Alfabeta, 2008.

Sutrisno, Fazlur Rahman Kajian Terhadap Metode, and Fazlur Rahman Kajian terhadap Metode. “Epistemologi Dan Sistem Pendidikan.” Yogyakarta: Pustaka Pelajar, 2006.

Tafsir, Ahmad, Ahmad Supardi, Hasan Basri, Mahmud Mahmud, Opik Taufik Kurahman, Pupuh Fathurrahman, Tedi Priatna, Supriatna Supriatna, Uus Ruswandi, and Yaya Suryana. Cakrawala Pemikiran Pendidikan Islam. Vol. 1. Mimbar Pustaka: Media Tranformasi Pengetahuan, 2004. 